In Water quality assessments in the Mississippi Delta: Regional solutions, national scope. M.T. Nett, M.A. Locke, and D.A. Pennington, eds., ACS Symposium Ser. 877, pp. 179-193.

\title{
Spatial Variability of Cyanazine Dissipation in Soil from a Conservation-Managed Field
}

\author{
William J. Staddon ${ }^{1,2}$, Martin A. Locke ${ }^{1,3 *}$, and Robert M. \\ Zablotowicz $^{1}$ \\ ${ }^{1}$ USDA-Agricultural Research Service, Southern Weed Science Research \\ Unit, Stoneville, MS, 38776 \\ ${ }^{2}$ Department of Biological Sciences, Eastern Kentucky University, \\ Richmond, KY 40475 \\ ${ }^{3}$ Current address: USDA-Agricultural Research Service, National \\ Sedimentation Laboratory, Water Quality and Ecological Processes \\ Research Unit, Oxford, MS 38655
}

Assessment of soil spatial characteristics may provide the basis for using precision application of herbicides to reduce chemical inputs. Spatial variability of cyanazine degradation and sorption in relation to soil characteristics were examined in soil from a reduced-tillage cotton field (2 ha, no-tillage, wheat cover crop) in the Mississippi Delta Management Systems Evaluation Area (MDMSEA) Deep Hollow Lake watershed. Soil was sampled in a grid pattern $(n=100)$, and samples were collected in spring, 1999. Soil characteristics evaluated included $\mathrm{pH}$, \% organic matter $(\mathrm{OM})$, texture, cyanazine sorption, and microbial metabolic activity. Cyanazine degradation during laboratory incubation (28 d) was assessed using ${ }^{14} \mathrm{C}$-labeled cyanazine. Subsamples were extracted with methanol, processed, and analyzed by thin layer chromatography. Cyanazine sorption was measured using batch methods. Half-lives of cyanazine ranged from 5 to 26 days with the greatest persistence correlated with the highest soil clay content $(\mathrm{r}=0.73)$ and negatively correlated with $\mathrm{pH}(\mathrm{r}=-.80)$. Major metabolites observed were cyanazine 
amide and polar hydroxy derivatives. Spatial trends were modeled using a surface quadratic equation and geostatistics, and data were detrended where appropriate. Many parameters, such as cyanazine sorption, showed highly significant trends across the field. Cyanazine half-life and metabolite accumulation had spatial structure that could be modeled with a semivariogram, while no spatial structure was observed for soil OM.

Considerable effort has been directed towards characterizing the fate of herbicides in agricultural systems. Laboratory experiments have examined herbicide sorption and degradation while field studies have provided insights into the roles of leaching and surface runoff. A few reviews have been published concerning the role of tillage practices, soil organic matter, clay, $\mathrm{pH}$, and microbial activity on the dissipation of herbicides in the environment $(1,2)$. Most current knowledge about herbicide dissipation comes from studies involving traditional small plot designs. However, agricultural lands are spatially heterogeneous, and relatively few studies have assessed variability of herbicide fate within fields and watersheds $(3,4)$.

In the past decade, development of technologies such as global positioning systems (GPS) and geographic information systems (GIS) have spurred interest in evaluating relationships between the spatial properties of soil and agrochemical application (5). Spatial characterization of agricultural land, in particular soil properties, should provide the theoretical and practical knowledge needed for precision agricultural management (6). Application of fertilizer and herbicides can be varied to better match localized conditions within a field (5, 6 , 7). Spatial studies have benefited from the use of geostatistics, a statistical approach developed by the mining industry for non-random situations (8). Specifically, variography is used to assess the presence of localized spatial dependence or autocorrelation for a parameter. This technique provides additional insight into the variability of soil properties (9). Although the spatial variability of herbicide fate has been investigated, few studies have incorporated geostatistics $(10,11,12,13)$.

Cyanazine has been used in a variety of herbicide treatment regimes, including directed post-emergence in cotton for the control of broadleaf weeds and grasses. Degradation of cyanazine is generally thought to be a nonbiological process, primarily hydrolysis, to amide and hydroxyl metabolites (14, 15). Soil parameters such as $\mathrm{OM}, \mathrm{pH}$, and water content play a role in the fate of cyanazine in the agricultural environment $(16,17)$. Further, soil properties such as OM content and cation exchange capacity influence the efficacy of cyanazine as a preemergence herbicide (18). Since surface soils in conservation 
tillage systems tend to have enhanced OM contents, herbicide dissipation may be influenced (1). Greater cyanazine sorption was observed in no-till and plant residue amended soils than in corresponding conventional tillage soils (19). Increased $\mathrm{OM}$ and plant residue accumulation can reduce cyanazine loss in surface runoff (20), but lower water runoff and increased preferential flow through soil profiles often results in greater herbicide leaching $(20,21)$.

The objective of this study was to characterize the spatial variability of cyanazine fate in a cotton field managed using conservation practices. Assessment of relationships between soil spatial characteristics and herbicide dissipation may provide a basis for using precision application of herbicides to reduce chemical inputs in conservation management systems.

\section{Materials and Methods}

\section{Study Site and Sample Preparation}

Soil from a MDMSEA study site under reduced-tillage management in Leflore County, Mississippi (Deep Hollow Lake watershed) was investigated in 1999. Winter wheat had been planted as a cover crop following cotton every

year since 1995. The study site was last subsoiled and disked in the fall of 1997, and lime also was applied in the fall of $1997\left(1100 \mathrm{~kg} \mathrm{ha}^{-1}\right)$. Other details about the study area are described elsewhere in this volume (Chapter by Locke, this volume).

A grid following an equilateral triangle pattern (12.2 m between sampling points) was established (100 sampling locations) within approximately a 2-ha area. Surface $(0-5 \mathrm{~cm})$ soil samples were collected on April 30, 1999, after cover crop desiccation, but before cotton planting. Each sample was a composite of six cores (5 cm diameter) collected from within the seedbed area of the cotton rows. Field-moist samples from each grid were pooled, sieved (4 $\mathrm{mm}$ mesh) and stored at $4^{\circ} \mathrm{C}$ until further use. Air-dried soils were analyzed for soil pH (soil:water, 1:2) and OM content (Walkley Black method). Soil texture was ascertained using the hydrometer method. Microbial metabolic activity of field moist soil was estimated using triphenyl-tetrazolium chloride (TTC) dehydrogenase activity as described elsewhere (22). 


\section{Cyanazine Degradation}

Soil, 24 g (air-dry weight equivalent) was added to Nalgene bottles and adjusted to $30 \%(\mathrm{~g} / \mathrm{g})$ moisture. Uniformly ring ${ }^{14} \mathrm{C}$-labeled cyanazine (E.I. Dupont de Nemours and Co., Wilmington, DE) was added to the soil at a concentration of $10.4 \mu \mathrm{mol} \mathrm{kg}{ }^{-1}$ (approximate equivalent to $2.1 \mathrm{~kg} \mathrm{ha}^{-1}$ ) and radioactivity of $485 \mathrm{kBq} \mathrm{kg}^{-1}$. Treated soils were vortexed for uniform mixing and incubated at $25^{\circ} \mathrm{C}$. The lids were placed loosely on the sample bottles, and moisture levels were adjusted periodically to compensate for drying. Subsampling was performed 0 , 2, 5, 9, 17 and 28 days after cyanazine treatment (3.5 $\mathrm{g}$ of soil on the first four sampling days, 4.5 grams on the last two). Subsamples were individually placed in 25-mL Corex tubes with Teflon lids, and extracted with methanol (2:1, methanol:soil) by shaking for $24 \mathrm{~h}$. After centrifugation at $7,700 \mathrm{x}$ g, the supernatants were decanted, and the soil was reextracted with methanol by shaking for $4 \mathrm{~h}$. Supernatants from the two extractions were combined, weighed, and radioactivity determined by liquid scintillation counting (Liquid Scintillation Counter Model 4430, Packard Instruments, Downers Grove, IL). The remaining volume of each extract was reduced to approximately $4 \mathrm{~mL}$ under $\mathrm{N}_{2}$. Aliquots $(100 \mu \mathrm{L})$ were spotted on thin layer chromatography (TLC) plates $(20 \times 20 \mathrm{~cm}, 250 \mu \mathrm{m}$ silica gel, Whatman, Clifton, NJ) and developed with an ethyl acetate:toluene:methanol (50:50:3, v:v:v) solvent system. Chromatography was analyzed using a Bioscan System 200 Imaging Scanner (Bioscan, Washington, D.C.). Cyanazine had an $\mathrm{R}_{\mathrm{f}}$ of approximately 0.77 . Two additional solvent systems were used for characterizing the metabolites in the $5 \mathrm{~d}$ and $28 \mathrm{~d}$ extracts: ethyl acetate:toluene:methanol 50:50:3; and ethyl acetate alone. Cyanazine metabolites were provided by E.I. Dupont de Nemours and Co. Air-dried soils from day 28 were oxidized to measure nonextractable ${ }^{14} \mathrm{C}$ (Oxidizer Model 306, Packard Instruments).

\section{Cyanazine Sorption}

Air-dried soil (5 g oven-dry equivalent) placed in 25-mL Corex tubes. Ten $\mathrm{mL}$ of ${ }^{14} \mathrm{C}$ cyanazine solution $\left(10 \mu \mathrm{mol} \mathrm{L}{ }^{-1}\right.$ cyanazine; $\left.162 \mathrm{kBq} \mathrm{g}^{-1}\right)$ were added to the tubes and shaken for 24 hours at $25^{\circ} \mathrm{C}$. After centrifugation $(8,000 \mathrm{x}$ g; $10 \mathrm{~min}$ ), radioactivity in aqueous samples was determined by liquid scintillation

counting. Cyanazine $K_{d}$ values were calculated as the distribution between cyanazine in solution at equilibrium and cyanazine sorbed to soil. 


\section{Data Analysis}

The half-lives of extractable total ${ }^{14} \mathrm{C}$ and extractable ${ }^{14} \mathrm{C}$ cyanazine data were fit to first-order kinetics using PCSAS NLIN procedure (SAS, Cary NC) (23). The first order degradation rate constant (K) and the 95\% confidence interval were calculated using the NLIN procedure, and the half-life was calculated from $\mathrm{K}$. Evidence of spatial structure in the data was assessed in two steps. First, a surface quadratic model was applied to identify trends in the data. Linear correlations from above were also used to confirm trends and other relationships. The second step examined the residuals remaining after detrending for spatial structure that could be modeled using geostatistics (GS+, Gamma Design Software, Plainwell, MI). Log transformations were applied when trends existed in the residuals. Models normally included 6 lag classes and an active lag distance approximately twice that of the range. Maps of the trends and raw data were created using Surfer Version 6 (Golden Software, Golden, CO) using the radial bias function.

\section{Results}

A summary of soil characteristics and cyanazine dissipation parameters is presented in Table I. Linear correlations between soil characteristics and cyanazine dissipation were determined in order to evaluate relationships between cyanazine degradation and soil chemical, physical, and biological properties (Table II). Multiple regression response surface analysis was used to determine whether parameter response was a function of direction eastward or westward across the field, which corresponded to changes in elevation from the top of the slope to the bottom. The soil in the 2-ha area was slightly acidic to neutral $\mathrm{pH}$, with relatively low organic matter content typical of many cultivated Mississippi Delta soils (Table I). Management under reduced tillage conditions resulted in an organic matter content only slightly elevated above adjacent conventional tillage soils (not part of this study) (24). Microbial activity as indicated by TTC-dehydrogenase activity was moderate (Table I).

All parameters except OM content were fit to significant multiple regression models as a function of direction. Two soil parameters, sand $\left(\mathrm{R}^{2}=0.85\right.$, Pr. $>\mathrm{F}$ $=0.0001)$ and clay $\left(R^{2}=0.88\right.$, Pr. $\left.>F=0.0001\right)$, had strong, but opposite trends across the field; sand tended to be higher at the top of the slope, while clay was higher at the bottom of the slope (24). Cyanazine sorption to soil also had a strong trend $\left(\mathrm{R}^{2}=0.88, \mathrm{Pr} .>\mathrm{F}=0.0001\right)$, with increasing sorption to soils sampled from areas further down the slope. These trends are in agreement with the linear correlation of cyanazine sorption to clay $(r=0.93$, Pr. $>F=0.0001)$ and sand $(r=-0.90$, Pr. $>F=0.0001)$, and support previous studies where clays 
had a higher capacity for cyanazine sorption (25). Several other parameters, such as extractable cyanazine amide at days 5 and 28, extractable hydroxy cyanazine derivatives and nonextractable ${ }^{14} \mathrm{C}$ at day 28 , soil $\mathrm{pH}$, and cyanazine half-life, had significant (Pr. > F = 0.0001), but moderate, surface response regressions as a function of direction across the field $\left(\mathrm{R}^{2}\right.$ range from 0.40 to

Table I. Summary of Characteristics and Cyanazine Degradation Parameters in Soil from a No-Till, Wheat Cover Crop Managed Field.

\begin{tabular}{lllll} 
Parameter* & Mean & $\begin{array}{l}\text { Standard } \\
\text { deviation }\end{array}$ & $\begin{array}{l}\text { Minimum } \\
\text { value }\end{array}$ & $\begin{array}{l}\text { Maximum } \\
\text { value }\end{array}$ \\
\hline Soil pH & 6.40 & 0.48 & 4.54 & 7.07 \\
Soil Organic Matter (\%) & 1.13 & 0.21 & 0.70 & 1.80 \\
Clay (\%) & 17.9 & 7.3 & 10.1 & 36.7 \\
Sand (\%) & 31.4 & 10.4 & 10.2 & 45.2 \\
$\begin{array}{l}\text { TTC-dehydrogenase } \\
\text { Cyanazine sorption (Kd) }\end{array}$ & 18.7 & 5.56 & 8.13 & 37.0 \\
$\begin{array}{l}\text { Half-life total } \\
\text { extractable }{ }^{14} \mathrm{C}(\mathrm{d})\end{array}$ & 24.6 & 0.38 & 0.73 & 2.27 \\
$\begin{array}{l}\text { Half-life cyanazine (d) } \\
\begin{array}{l}\text { Hydroxy cyanazine } \\
\text { derivatives, 5 d (\%) }\end{array}\end{array}$ & 8.60 & 4.05 & 5.44 & 26.2 \\
$\begin{array}{l}\text { Cyanazine amide, 5 d } \\
\text { (\%) }\end{array}$ & 18.0 & 4.09 & 7.07 & 27.7 \\
$\begin{array}{l}\text { Hydroxy cyanazine } \\
\text { derivatives, 28 d (\%) }\end{array}$ & 38.6 & 12.30 & 3.57 & 56.5 \\
$\begin{array}{l}\text { Cyanazine amide, 28 d } \\
\text { (\%) }\end{array}$ & 5.30 & 5.55 & 0 & 22.4 \\
$\begin{array}{l}\text { Non-extractable }{ }^{14} \mathrm{C}, 28 \\
\text { d (\%) }\end{array}$ & 26.4 & 6.08 & 15.6 & 41.4 \\
\hline
\end{tabular}

*Units for TTC-dehydrogenase activity are nmole $\mathrm{g}^{-1}$ soil $^{-1}$

Units for cyanazine sorption $\mathrm{Kd}$ are $\mathrm{L} \mathrm{kg}^{-1}$ 
Table II. Correlation Coefficient (r) and Prob > F Between Soil Properties and Cyanazine Degradation Parameters.

\begin{tabular}{|c|c|c|c|c|c|c|c|}
\hline $\begin{array}{l}\text { Soil } \\
\text { Characteristic }\end{array}$ & $\begin{array}{c}\text { Extractable } \\
\text { Total }{ }^{14} \mathrm{C} \\
\text { Half-life }\end{array}$ & $\begin{array}{c}\text { Cyanazine } \\
\text { Half-life }\end{array}$ & $\begin{array}{c}\text { Non- } \\
\text { extractable } \\
{ }^{14} \mathrm{C}(\mathrm{d} 28)\end{array}$ & $\begin{array}{l}\text { Polar } \\
\text { Hydroxy } \\
\text { Cyanazine } \\
\text { (d 5) }\end{array}$ & $\begin{array}{l}\text { Cyanazine } \\
\text { Amide } \\
\text { (d 5) }\end{array}$ & $\begin{array}{c}\text { Polar } \\
\text { Hydroxy } \\
\text { Cyanazine } \\
\text { (d 28) }\end{array}$ & $\begin{array}{c}\text { Cyanazine } \\
\text { Amide } \\
\text { (d 28) }\end{array}$ \\
\hline $\mathrm{pH}$ & $\begin{array}{l}0.69 * \\
0.001^{* *}\end{array}$ & $\begin{array}{l}-0.80 \\
0.001\end{array}$ & $\begin{array}{l}-0.61 \\
0.001\end{array}$ & $\begin{array}{l}0.62 \\
0.001\end{array}$ & $\begin{array}{l}0.50 \\
0.001\end{array}$ & $\begin{array}{l}0.84 \\
0.001\end{array}$ & $\begin{array}{l}-0.71 \\
0.001\end{array}$ \\
\hline $\begin{array}{l}\text { Soil Organic } \\
\text { Matter }\end{array}$ & $\begin{array}{l}0.09 \\
\mathrm{NS}\end{array}$ & $\begin{array}{r}-0.20 \\
0.05\end{array}$ & $\begin{array}{l}0.13 \\
\text { NS }\end{array}$ & $\begin{array}{l}0.31 \\
0.002\end{array}$ & $\begin{array}{l}-0.06 \\
\text { NS }\end{array}$ & $\begin{array}{l}0.22 \\
0.03\end{array}$ & $\begin{array}{l}-0.30 \\
0.003\end{array}$ \\
\hline Clay (\%) & $\begin{array}{l}-0.50 \\
0.001\end{array}$ & $\begin{array}{l}0.73 \\
0.001\end{array}$ & $\begin{array}{l}0.72 \\
0.001\end{array}$ & $\begin{array}{l}-0.50 \\
0.001\end{array}$ & $\begin{array}{l}-0.69 \\
0.001\end{array}$ & $\begin{array}{c}-0.74 \\
0.001\end{array}$ & $\begin{array}{l}0.62 \\
0.001\end{array}$ \\
\hline Sand (\%) & $\begin{array}{l}0.41 \\
0.001\end{array}$ & $\begin{array}{l}-0.69 \\
0.001\end{array}$ & $\begin{array}{l}-0.75 \\
0.001\end{array}$ & $\begin{array}{l}0.45 \\
0.001\end{array}$ & $\begin{array}{l}0.67 \\
0.001\end{array}$ & $\begin{array}{l}0.69 \\
0.001\end{array}$ & $\begin{array}{c}-0.58 \\
0.001\end{array}$ \\
\hline $\begin{array}{l}\text { Cyanazine } \\
\text { Sorption (\%) }\end{array}$ & $\begin{array}{c}-0.57 \\
0.001\end{array}$ & $\begin{array}{l}0.80 \\
0.001\end{array}$ & $\begin{array}{c}0.78 \\
0.001\end{array}$ & $\begin{array}{l}-0.51 \\
0.001\end{array}$ & $\begin{array}{l}-0.69 \\
0.001\end{array}$ & $\begin{array}{c}-0.79 \\
0.001\end{array}$ & $\begin{array}{l}0.63 \\
0.001\end{array}$ \\
\hline TTC & $\begin{array}{l}-0.06 \\
\text { NS }\end{array}$ & $\begin{array}{l}0.12 \\
\text { NS }\end{array}$ & $\begin{array}{l}0.25 \\
0.01\end{array}$ & $\begin{array}{l}-0.02 \\
\mathrm{NS}\end{array}$ & $\begin{array}{r}-0.21 \\
0.04\end{array}$ & $\begin{array}{l}-0.10 \\
\text { NS }\end{array}$ & $\begin{array}{l}-0.01 \\
\text { NS }\end{array}$ \\
\hline
\end{tabular}

* Pearson Correlation coefficients (r); ** Probability > F; NS=Not Significant 
Table III. Spatial Characteristics of Soil Properties from a No-Till, Wheat Cover Crop Managed Field.

\begin{tabular}{|c|c|c|c|c|c|c|}
\hline Parameter & $\begin{array}{c}\text { Significance of } \\
\text { Trend }\end{array}$ & $\begin{array}{c}\text { Nugget } \\
\text { (Co) }\end{array}$ & $\begin{array}{c}\text { Sill } \\
(C o+C)\end{array}$ & $\begin{array}{c}Q \\
\bar{C} \\
(C o+C)\end{array}$ & $\begin{array}{l}\text { Range } e^{1} \\
\text { (Meters) }\end{array}$ & Model \\
\hline $\mathrm{pH}^{* *}$ & $\mathrm{P}<0.0001$ & 0.0221 & 0.1162 & 0.810 & 22.5 & Spherical \\
\hline Clay & $\mathrm{P}<0.0001$ & 0.0024 & 0.0048 & 0.500 & 62.4 & Spherical \\
\hline $\mathrm{OM}^{* * *}$ & No Trend & NSS & & & & \\
\hline TTC*,** & $\mathrm{P}<0.0001$ & 0.0043 & 0.0147 & 0.707 & 23.5 & Exponential \\
\hline
\end{tabular}

${ }^{1}$ Value is the effective range when exponential model is used.

* Log transformations were performed to removed trends in the residuals.

**Indicates that spatial structure is not conclusive.

$* * *$ NSS found in raw data 
0.57). Cyanazine half-life, nonextractable ${ }^{14} \mathrm{C}$ at day 28 , and soil $\mathrm{pH}$ tended to be higher in soil sampled from downslope, while cyanazine amide at day 5 and hydroxy cyanazine at day 28 were lower. Linear correlations between cyanazine half-life and clay were positive, while half-life was lower with increasing sand (Table II). Surface response regression with direction accounted for much less of the variability (Pr. > F 0.0001) in TTCdehydrogenase activity $\left(\mathrm{R}^{2}=0.25\right)$, extractable polar hydroxy cyanazine at day $5\left(R^{2}=0.25\right)$, and total extractable ${ }^{14} C$ half-life $\left(R^{2}=0.27\right)$. Polar hydroxy cyanazine derivatives at day 5 and extractable ${ }^{14} \mathrm{C}$ half-life were negatively correlated with clay and positively correlated with sand (Table II). There was limited relationship between microbial activity based upon TTC-dehydrogenase activity and cyanazine degradation parameters, except for non-extractable ${ }^{14} \mathrm{C}$ residues and cyanazine amide at $\mathrm{d} 28$.

Geostatistical evaluations were made to try to ascertain sources of variation other than direction across the field. Similar to the multiple regression analysis,

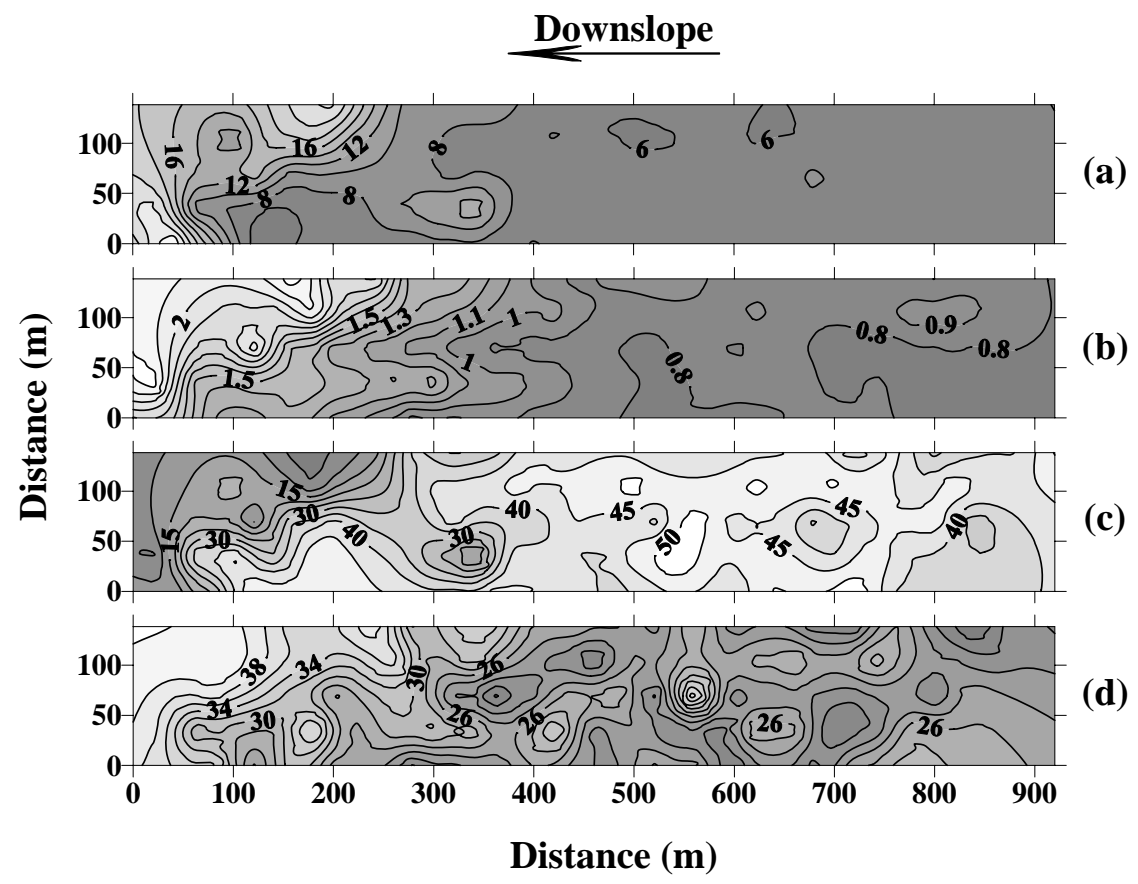

Figure 1. Semivariograms showing spatial distribution of selected parameters across the study area. (a) Cyanazine half-life (days); (b) Cyanazine sorption $\left(K_{d}\right)$; (c) \% polar cyanazine metabolites d 28; (d) \% non-extractable ${ }^{14} \mathrm{C} d 28$.

all parameters, with the exception of OM content, had trends that could be modeled with a surface quadratic equation (Table III). For several parameters, including cyanazine half-life (Figure 1a) and sorption (Figure 1b), the greatest variations occurred at the west end of the field (bottom of slope). Trends were removed from the data and variography was performed on the residuals. No spatial structure could be modeled in the residuals for sorption, nonextractable ${ }^{14} \mathrm{C}$ on day 28 , nor the polar metabolites and cyanazine amide on day 28 (Tables 
III and IV). For these parameters, no spatial dependence existed over distances greater than $12.2 \mathrm{~m}$ (shortest distance between plots) other than the trend. However, this also suggests that spatial structure may have occurred at distances less than the shortest lag interval (12.2 m).

For parameters such as $\mathrm{pH}$, TTC-dehydrogenase activity, and half-life of extractable ${ }^{14} \mathrm{C}$, trends were removed, and it was determined that there was significant spatial structure in the residuals (Tables III and V). Semivariograms were modeled for the residuals of these parameters. These results suggest that for these parameters, in addition to the trend, spatial structure exists at distances greater than $12.2 \mathrm{~m}$. Samples taken at these distances lack independence due to the trend (detected using the surface quadratic model) as well as localized autocorrelation (modeled using a semivariogram).

\section{Discussion}

No spatial structure, either trend or autocorrelation, was found for OM (Table III). In contrast, both a trend and spatial structure in the residuals for OM were observed in samples taken from the same positions the previous year (June, 1998) (24). These results demonstrate that the spatial structure of OM can change over a short period of time on sites where residue management is practiced. Overall, OM for 1998 was $1.02 \%$ (0.7 to 1.5 ) versus $1.13 \%$ (0.7 to 1.8) for 1999. With time, reduced tillage management at this location may result in even higher OM contents (24). The changes in OM are dependent on the growth of plants and subsequent plant material decomposition. Within a field, accumulation of plant residues and subsequent decomposition may be extremely variable, not necessarily related to soil characteristics, such as clay. This may have resulted in the lack of spatial structure observed in this area for OM.

The highest levels of cyanazine sorption occurred at the west end of the field (Figure 1a), an area that had highest levels of clay in the field. Sorption, however, did not appear to be related to OM in this study. These results vary with other studies (18) where the amount of cyanazine needed for weed control was directly related to soil organic matter. Reddy et al. (19) observed that cyanazine sorption was greater in no-tillage surface soil that had higher OM 
Table IV. Summary of Spatial Characteristics of Cyanazine Metabolite Accumulation in Soil from a No-Till, Wheat Cover Crop Managed Field, Based on Thin Layer Chromatography Analysis 5 and $28 \mathrm{~d}$ after Treatment.

\begin{tabular}{|c|c|c|c|c|c|c|}
\hline Parameter & $\begin{array}{l}\text { Significance } \\
\text { of Trend }\end{array}$ & $\begin{array}{l}\text { Nugget } \\
\text { Co }\end{array}$ & $\begin{array}{c}\text { Sill } \\
\text { Co+ }+C\end{array}$ & $\begin{array}{c}Q \\
C \\
(C o+C)\end{array}$ & $\begin{array}{l}\text { Range }^{1} \\
\text { (Meters) }\end{array}$ & Model \\
\hline $\begin{array}{l}\text { Polar metabolites } \\
\text { (d 5)* }\end{array}$ & $\mathrm{p}<0.0001$ & 7.78 & 27.27 & 0.715 & 29.3 & Exponential \\
\hline $\begin{array}{l}\text { Cyanazine amide } \\
\text { (d 5)* }\end{array}$ & $\mathrm{p}<0.0001$ & 2.59 & 10.79 & 0.760 & 21.9 & Spherical \\
\hline $\begin{array}{l}\text { Polar metabolites } \\
\text { (d 28)** }\end{array}$ & $\mathrm{p}<0.0001$ & NSS & & & & \\
\hline $\begin{array}{l}\text { Cyanazine amide } \\
\text { (d 28)** }\end{array}$ & $\mathrm{p}<0.0001$ & NSS & & & & \\
\hline
\end{tabular}

${ }^{1}$ Value is the effective range when exponential model is used.

*Indicates that spatial structure is not conclusive.

**No spatial structure (NSS) value is over short lag distances $(<100 \mathrm{~m})$ - semivariance did increase at larger lag intervals but no sill/range could be modeled 
Table V. Summary of Spatial Characteristics of Cyanazine Dissipation, $\left({ }^{14} \mathrm{C}\right.$ Half-Life, Cyanazine Half-Life, NonExtractable ${ }^{14} \mathrm{C}$ at $28 \mathrm{~d}$, and Cyanazine Sorption) in Soil from a No-Till, Wheat Cover Crop Managed Field.

\begin{tabular}{|c|c|c|c|c|c|c|}
\hline Parameter & $\begin{array}{l}\text { Significance of } \\
\text { Trend }\end{array}$ & $\begin{array}{l}\text { Nugget } \\
\text { Co }\end{array}$ & $\begin{array}{c}\text { Sill } \\
\text { Co+ }+C\end{array}$ & $\begin{array}{c}Q \\
C \\
(C o+C)\end{array}$ & $\begin{array}{l}\text { Range } \\
\text { meters }\end{array}$ & Model \\
\hline $\begin{array}{l}\text { Extractable }{ }^{14} \mathrm{C} \\
\text { Half-life }\end{array}$ & $P=0.0216$ & 24.20 & 63.64 & 0.620 & 77.7 & Exponential \\
\hline $\begin{array}{l}\text { Cyanazine half- } \\
\text { life*,** }\end{array}$ & $\mathrm{P}<0.0001$ & 0.0015 & 0.0090 & 0.831 & 28.1 & Spherical \\
\hline $\begin{array}{l}\text { Non-extractable } \\
{ }^{14} \mathrm{C},(\mathrm{d} 28) * * *\end{array}$ & $\mathrm{P}<0.0001$ & NSS & & & & \\
\hline Sorption $* * *$ & $\mathrm{P}<0.0001$ & NSS & & & & \\
\hline
\end{tabular}

${ }^{1}$ Value is the effective range when exponential model is used.

* Log transformations were performed to removed trends in the residuals.

**Indicates that spatial structure is not conclusive.

***No spatial structure (NSS) value is over short lag distances $(<100 \mathrm{~m})$ - semivariance did increase at larger lag intervals but no sill/range could be modeled 
content than a corresponding conventional tillage soil. In this study, there was higher cyanazine sorption in the more acidic soil samples, reflecting increased affinity of the protonated herbicide with soil (16). Cyanazine sorption was also positively correlated with nonextractable ${ }^{14} \mathrm{C}$ at 28 days (Table II), indicating that some of the same factors enhancing sorption are also related to irreversible binding. For example, methanol-extractable hydroxy cyanazine was negatively correlated with sorption (Table II) and nonextractable ${ }^{14} \mathrm{C}(\mathrm{r}=-0.62$, Pr. $>\mathrm{F}=$ 0.0001). Other research has shown that hydroxy atrazine and cyanazine have a high affinity for soil and may not be completely extractable in methanol (17, 26). Since methanol was used as an extractant in the present study, it is likely that a portion of the hydroxy cyanazine derivatives were not extracted, thus contributing to the negative correlation with sorption and nonextractable ${ }^{14} \mathrm{C}$.

Half-lives for cyanazine (5 to 26 days) are consistent with those reported in other studies $(27,28)$. Cyanazine half-life in soil was correlated positively with clay and negatively with $\mathrm{pH}$ (Table II, Figure 1a). Blumhorst and Weber (16) also observed an inverse relationship between $\mathrm{pH}$ and cyanazine half-life. In other research (18), however, they did not find a relationship between cyanazine bioactivity and clay content. The half-life of cyanazine was also positively correlated with sorption (Table II). Previous research supports evidence that herbicide sorption to soil contributes to protecting herbicide from degradation $(16,29)$. Either an increase in clay or more acidic conditions would increase sorption and reduce cyanazine degradation, thereby supporting the correlations observed with sorption and half-life.

Chemical degradation of cyanazine is $\mathrm{pH}$-mediated, occurring under both low acidic ( $\mathrm{pH} \mathrm{4)}$ and alkaline conditions ( $\mathrm{pH} 10)$, with both dechlorination and nitrile hydrolysis occurring (30). Other research (14) indicated the major pathway for cyanazine degradation in soil was hydrolysis of the nitrile first to the amide, secondary hydrolysis of the amide to the acid, followed by dechlorination, with the major metabolite, the hydroxylated acid derivative, accumulating. In these present studies, the relationship between soil $\mathrm{pH}$ and extractable cyanazine metabolites was evident (Table II), but the $\mathrm{pH}$ range (Table I) was not at the extremes for pure chemical hydrolysis.

As soil $\mathrm{pH}$ approaches neutrality, biological degradation becomes more important, even though it was not evident by TTC levels in this study. TTC, although typically an indicator of microbial respiration (22), did not correlate with any parameter of cyanazine degradation, except for nonextractable ${ }^{14} \mathrm{C}$ at day 28. Blumhorst and Weber (16) suggested that formation of cyanazine amide and acid under neutral conditions was likely due to microbial activity. Wagner et al. (31) found that enhanced cyanazine degradation occurred upon the addition of crop residues or poultry manure that stimulated microbial activity.

Numerous bacterial cultures, e.g., Pseudomonas sp. ADP (32), Rhizobium strain PATR (33), Alcaligines strain SG1 (34), Agrobacterium radiobacter J14a 
(35), and Ralstonia picketti (36), have been shown to hydrolytically dehalogenate the related triazine, atrazine, via atrazine chlorohydrolase activity. The only atrazine-dechlorinating bacterial strain that has been shown to metabolize cyanazine is the $A$. radiobacter strain, thus limited information is available on microbial dechlorination of cyanazine (35).

In the present study, the polar derivatives (remaining at the origin in all three TLC solvents) corresponded with the $\mathrm{R}_{\mathrm{f}}$ of hydroxy cyanazine derivatives (hydroxy cyanazine and hydroxy cyanazine acid). The highest accumulation of hydroxy derivatives (40 to 56\%) was observed under more neutral soils at day 28 , while the cyanazine amide $\left(R_{f} 0.23\right)$ was found to be present only under slightly more acidic soil conditions. Very little cyanazine acid $(<5 \%)$ was detected in the samples. Since cyanazine amide is one of the first byproducts of cyanazine degradation and is transient, its degradation pattern during incubation is a reflection of that of the parent, cyanazine. More extractable cyanazine amide was observed earlier (day 5) in the incubation period for most soils, regardless of variation in soil parameters (Table I). Extractable cyanazine amide early in the incubation, however, was positively correlated with soil $\mathrm{pH}$ and negatively correlated to clay (Table II), both soil factors important to cyanazine degradation. Cyanazine was degrading slower in soils with higher clay and lower $\mathrm{pH}$, and corresponding lower cyanazine amide in these soils is likely a direct result. The opposite trends were observed for soil $\mathrm{pH}$ and clay correlations with cyanazine amide extracted four weeks later (day 28) (Table II).

In conclusion, the fate of cyanazine varied across the field. Regions with more acidic $\mathrm{pH}$ and higher clay contents had longer cyanazine half-lives. In the remainder of the field, hydroxy cyanazine derivatives appeared to be the primary metabolite produced, especially during the latter part of the incubation period. These observations may have implications for precision farming strategies. If an objective is to determine where changes in soil characteristics occur so that varying rates of chemicals can be applied, it is important to know where trends in soil characteristics occur within the field. Spatial structure is a significant issue for sampling in a research setting. For statistical purposes, samples must be independent, and this condition is not met if samples are taken where a trend or localized autocorrelation exists.

\section{References}

1. Locke, M.A.; Bryson, C.T. Weed Sci. 1997, 45, 307-320.

2. Fawcett, R.S.; Christensen, B.R.; Tierney, D.P. J. Soil Water Conserv. 1994, 49, 126-135.

3. Oliveira, R.S.; Koskinen, W.C.; Ferreira, F.A.; Khakural, B.R.; Mulla, D.J.; Rober, P.J. Weed Science, 1999, 47, 243-248. 
4. Locke, M.A.; Zablotowicz, R.M.; Gaston, L.A. In Environmental fate of fluometuron in a Mississippi Delta lake watershed; Arthur, E.L., Barefoot, A.C., and Clay, V.E., Eds.; Terrestrial field dissipation studies: Purpose, design, and interpretation, ACS Symposium Ser. 842; American Chemical Society, Washington, DC, 2002, pp. 206-225.

5. Al-Gaadi, K.A.; Ayers, P.D. Appl. Engin. Agric. 1999, 15, 255-262.

6. Wibawa, W.D.; Dludlu, D.L.; Swenson, L.J.; Hopkins, D.G.; Dahnke, W.C. J. Prod. Agric. 1993, 6, 255-261.

7. Rew, L.J.; Cussans, G.W.; Mugglestone, M.A.; Miller, P.C.H. Weed Res. 1996, 36, 283-292.

8. Trangmar, B.B.; Yost, R.S.; Uehara, G. Adv. Agron. 1985, 38, 45-94.

9. Cambardella, C.A.; Moorman, T.B.; Novak, J.M.; Parkin, T.B.; Karlen, D.L.; Turco, R.F.; Konopka, A.E. Soil Sci. Soc. Am. J. 1994, 58, 15011511.

10. Gaston, L.A.; Locke, M.A.; Zablotowicz, R.M.; Reddy, K.N. Soil Sci. Soc. Am. J., 2001, 65, 449-460.

11. Bending, G.D.; E. Shaw, E.; Walker, A. Biol. Fertility Soils 2001, 33, 484-489.

12. Novak, J.M.; T.B. Moorman, T.B.; Cambardella, C.A. J. Environ. Qual. 1997, 26, 1271-1277.

13. Jacques, D.; Mouvet, M.; Mohanty, B.; Vereecken, H.; Feyen, J. J. Contam. Hydrol. 1999, 36, 31-52.

14. Beynon, K.I.; Stoydin, G.; Wright, A.N. Pestic. Sci. 1972, 3, 293-305.

15. Sirons, G.J.; Frank, R.; Sawyer, T. J. Agr. Food Chem. 1973, 21, 10161020.

16. Blumhorst, M. R.; Weber, J. B. Pestic. Sci. 1994, 42, 79-84.

17. Blumhorst, M.R.; Weber, J.B.; J. Agric. Food Chem. 1992, 40, 894-897.

18. Blumhorst, M.R.; Weber, J.B.; Swain, L.R. Weed Technol. 1990, 4, 279283.

19. Reddy, K. N.; Locke, M.A.; Gaston, L.A. Soil Sci. 1997, 162, 501-510.

20. Hall, J.K; Mumma, R.O; Watts, D.W. Agr. Ecosystem Environ. 1991, 37, 303-314.

21. Isensee, A. R.; Sadeghi, A. M. Chemosphere 1995, 30, 671-685.

22. Staddon, W.J.; Locke, M.A.; Zabolotowicz, R.M. Soil Sci. Soc. Am. J. 2001, 65, 1136-1142.

23. Hamaker, J.W. In Organic chemicals in the soil environment. Vol I. C.A.I. Goring; Hamaker J.W. Eds. Marcel Dekker, New York. 1972, pp. 253-279.

24. Locke, M.A., W.J. Staddon, R.M. Zablotowicz, and S.M. Dabney. In Nutrient distribution in reduced tillage and conventional tillage cotton soils, Rebich, R.A., Knight, S.S., Eds.; The Mississippi Delta Management Systems Evaluation Areas project, 1995-1999. Mississippi Agric. Forestry Exper. Sta. Inform. Bull. 377, 2001, pp. 144-148. 
25. Reddy, K.N.; Locke, M.A.; Zablotowicz, R.M. Weed Sci. 1997, 45, 727732.

26. Lerch, R.N.; Thurman, E.M.; Blanchard, P.E. Environ. Toxicol. Chem. 1999, 18, 2161-2168.

27. Beynon, K.I.; Bosio, P.; Elgar, K.E. Pestic. Sci. 1972, 3, 401-408.

28. Helling, C.S.; Zhuang, W.; Gish, T.J.; Coffman, C.B.; Isensee, A.R.; Kearney, P.C.; Hoagland, D.R.; Woodward, M.D. Chemosphere 1988, 17, 175-187.

29. Lehmann, R.G.; Miller, J.R.; Fontaine, D.D.; Laskowski, D.A.; Hunter, J.H.; Cordes, R.C. Weed Res. 1992, 32, 197-205.

30. Brown, N.P.H.; Furmidge, G.G.L.; Grayson, B.T. Pestic. Sci. 1972, 3, 669678.

31. Wagner, S.C.; Zablotowicz, R.M. J. Environ. Sci. Health 1997, B32, 3754.

32. de Souza, M.L.; Sadowsky, M.J.; Wackett, L.P. J. Bacteriol. 1996, 178, 4894-4900.

33. Bouchard, C.J.; Ouazzani, J.; Prome, J.-C.; Michel-Briand, Y.; Plesiant, P. Appl. Environ. Microbiol. 1997, 63, 862-866.

34. de Souza, M.L.; Seffernick, J.; Martinez, B.; Sadowsky, M.J.; Wackett, L.P. J. Bacteriol. 1998, 180, 1951-1954.

35. Struthers, J.K.; Jayachandran, K.K.; Moorman, T.B. Appl. Environ. Microbiol. 1998, 64, 3368-3375.

36. Radosevich, M.; Traina, S.J.; Hao, Y.; Tuovinen. Appl. Environ. Microbiol. 1995, 61, 297-302. 